УДК $378.046-021.68: 316.61]: 004$

DOI: https://doi.org/10.35387/od.2(18).2020.66-75

Бойчук Юрій Дмитрович - доктор педагогічних наук, профресор, член-кореспондент НАПН України, проректор з наукової роботи Харківського національного педагогічного університету імені Г.С. Сковороди

ORCID iD: https://orcid.org/0000-0001-8583-5856

E-mail: yurij.boychuk@gmail.com

Казачінер Олена Семенівна - доктор педагогічних наук, доцент кафредри здоров'я людини, реабілітології $і$ спеціальної психології Харківського національного педагогічного університету імені Г.С. Сковороди

ORCID iD: https://orcid.org/0000-0003-4842-3857

E-mail:elena.kazachiner@gmail.com

\title{
РОЗВИТОК ІНКЛЮЗИВНОЇ КОМПЕТЕНТНОСТІ ВЧИТЕЛІВ У СИСТЕМІ ПІСЛЯДИПЛОМНОЇ ОСВІТИ ЗАСОБАМИ ІКТ
}

Анотація. В оглядовій статті доведено необхідність розвитку інклюзивної компетентності вчителів у системі післядипломної освіти. Традиційна організація підвищення рівня інклюзивної компетентності вчителів у системі післядипломної освіти в рамках стаціонарних курсів недостатньо ефективна. На сучасному етапі виникає проблема небажання вчителів працювати з дітьми з особливими освітніми потребами. Причинами цього $є$ психологічні бар'єри, професійні стереотипи вчителів та брак доступу до значного обсягу новітньої інфрормації, яка наявна в сучасних дослідженнях.

Доведено, що стрімкі зміни в розвитку інфрормаційних технологій надають більш широкі можливості сучасному вчителеві здобувати необхідні профресійні знання, зокрема щодо навчання дітей із особливими освітніми потребами. Проаналізовано методичні й організаційні аспекти використання IKT-супроводу для розвитку цього виду компетентності вчителя як складової його профресійної компетентності. Обрано освітні україномовні та англомовні платформи, що містять різноманітні он лайн курси та вебінари з різних питань упровадження інклюзивного навчання в заклади загальної середньої освіти. Висвітлено технологічні можливості україномовних та англомовних освітніх платформ edera.com, futurelearn.com, elt.oup.com, coursera.org, vseosvita.ua за визначеними критеріями (наявність курсів та вебінарів із різноманітних питань організації та впровадження концептуальних ідей та положень інклюзивного навчання в закладах загальної середньої освіти; практична спрямованість контенту; зручність інтерфейсу; змістове наповнення; якість он лайн зв'язку з учасником; фрінансова доступність) та підходи, 
що дають змогу сприяти ефективному розвитку інклюзивної компетентності вчителів у системі післядипломної освіти.

У статті запропоновано удосконалену організацію підвищення рівня інклюзивної компетентності в системі післядипломної освіти, яка передбачає поряд із традиційним навчанням у рамках стаціонарних курсів участь учителів у он лайн курсах та вебінарах, розташованих на різноманітних освітніх платформах в Інтернеті, за допомогою використання інфоормаційно-комунікаційних технологій.

Ключові слова: післядипломна освіта; інклюзивна компетентність учителя; інформаційно-комунікаційні технології

Boychuk Yuriy - Doctor of Pedagogical Sciences, Professor, Correspondent Member of NAES of Ukraine, Vice-Rector for Research of the H.S. Skovoroda Kharkiv National Peddagogical University

ORCID iD: https://orcid.org/0000-0001-8583-5856

E-mail: yurij.boychuk@gmail.com

Kazachiner Olena - Doctor of Pedagogical Sciences, Associate Professor of Human Health, Rehabilitology and Special Psychology Department, H.S. Skovoroda Kharkiv National Peddagogical University

ORCID iD: https://orcid.org/0000-0003-4842-3857

E-mail:elena.kazachiner@gmail.com

\section{DEVELOPING TEACHERS' INCLUSIVE COMPETENCE BY MEANS OF ICT IN POSTGRADUATE EDUCATION}

Abstract. The traditional organization of increasing the teachers' level of inclusive competence in the system of postgraduate education in the framework of stationary courses is not effective enough. At the present stage, there is a problem of teachers' reluctance to work with children with special educational needs. One of the reasons for this is teachers' psychological barriers, professional stereotypes and lack of access to a large amount of the latest information that is available in modern research.

It is proved that rapid changes in information technologies development open up more opportunities for modern teachers to acquire the necessary professional knowledge for teaching children with special educational needs. The methodical and organizational aspects of ICT use for the development of this type of teacher's competence as a component of his professional competence are analyzed. Educational Ukrainian and Englishlanguage platforms containing various on-line courses and webinars on various issues of the introduction of inclusive education in institutions of general secondary education were selected. The technological opportunities of the Ukrainian-language and English-language educational platforms ed-era.com, futurelearn.com, elt.oup.com, coursera.org, vseosvita.ua are highlighted 
according to certain criteria (availability of courses and webinars on various issues of organization and implementation of conceptual ideas and provisions of inclusive education in institutions of general secondary education; practical orientation of the content; convenience of the interface; content filling; quality of online communication with the participant; financial availability) and approaches, which allow to promote effective development of teachers' inclusive competence in the system of postgraduate education.

The article offers an improved organization for increasing the level of inclusive competence in the postgraduate education, in which, along with traditional training in the framework of stationary courses, teachers, using ICT, participate in online courses and webinars posted on various educational platforms in the Internet.

Key words: postgraduate education; teacher's inclusive competence; information and communication technologies.

Постановка проблеми, іï актуальність. На сучасному етапі інноваційного розвитку освіти в Україні держава окреслює якісно нові вимоги до особистості вчителя, його професійної діяльності. Серед таких вимог особливе місце посідає реалізація педагогом засадничих принципів державної політики в галузі вітчизняної освіти, а саме: пріоритет освіти, її демократизація, гуманізація та гуманітаризація, рівний доступ громадян до здобуття освіти, цілісність, полікультурність, змінна й відкрита природа системи освіти, неподільний характер навчання та виховання. Реалізації зазначених принципів повною мірою сприяє впровадження основних положень та ідей інклюзивного навчання в заклади загальної середньої освіти.

Проте нині гостро постає проблема неготовності вчителів до роботи з дітьми, які мають особливі освітні потреби, наявні психологічні бар'єри та професійні стереотипи вчителів.

Дотепер у змісті освітніх програм закладів післядипломної педагогічної освіти не було теми «Технології інклюзивного навчання», тому має місце розрив між здобутою раніше професійною підготовкою та тією, яка має бути нині. У зв'язку з цим важливим стає розвиток інклюзивної компетентності вчителів як складової їхньої професійної компетентності. Посутню роль у створенні умов для цього відіграють заклади післядипломної педагогічної освіти, в яких здійснюється підвищення кваліфікації.

Володіння вчителями методами ІКТ дозволяє додатково здобувати значний обсяг знань у заочному та дистанційному режимі.

Аналіз останніх досліджень і публікацій. Нині в Україні склалися передумови для теоретичного й практичного розв'язання окресленої проблеми, це підтверджене ґрунтовними науковими працями, де схарактеризовано положення сучасної психолого-педагогічної науки про закономірності навчання дітей з особливими освітніми потребами та без 
них (В. Бондар, Елен Р. Даніелс, В. Засенко, А. Колупаєва, С. Кульбіда, Ю. Найда, Т. Сак, В. Синьов, Н. Софій, О. Таранченко, Р. Ghesquière, B. Maes, E. March, G. Moors та ін.). Питання формування інклюзивної компетентності педагогів та осіб, які працюють із дітьми з особливостями психофрізичного розвитку, було предметом наукового пошуку С. Альохіної, Л. Антонюк (Альохіна \& Антонюк, 2010), К. Бовкуш (Бовкуш, 2014), Ю. Бойчука, О. Бородіної (Бойчук, Бородіна \& Микитюк, 2015), О. Казачінер (Казачінер, 2017), І. Хафрізулліної (Хафрізулліна, 2007), В. Хитрюк (Хитрюк, 2014), М. Чайковського (Чайковський, 2012) та інших науковців.

Заслуговує на увагу низка розвідок, що стосуються саме застосування інформаційно-комунікаційних технологій для інклюзивної освіти, і підготовки вчителів у цьому напрямі, таких авторів, як А. Гета (Гета, Заіка \& Коваленко, 2018), Л. Голодюк (Голодюк, 2009), Л. Карташова (Карташова, Пліш \& Бахмат, 2018), О. Кравчина (Кравчина, 2018), Ю. Носенко (Носенко, 2016), О. Овчарук (Овчарук, Гриценчук, Іванюк, Кравчина, Галицька \& Сороко, 2018) та ін.

Мета статті - висвітлення удосконаленої організації навчання в системі післядипломної освіти, за якої поряд із традиційними методами в рамках стаціонарних курсів, має бути передбачено участь в онлайн курсах $\mathrm{i}$ вебінарах, розміщених на різних освітніх платформах в Інтернеті (за допомогою засобів інформаційно-комунікативних технологій (ІКТ).

Виклад основного матеріалу дослідження. Ми акцентуємо увагу на необхідності під час підвищення кваліфікації використовувати засоби IКT для участі в онлайн курсах і вебінарах, доступних в Інтернеті на різних освітніх платформах.

Обраний контент онлайн-курсів і вебінарів викладено у табл. 1.

Таблиця 1

Перелік онлайн курсів та вебінарів, що сприяють розвитку інклюзивної компетентності вчителів

\begin{tabular}{|c|c|}
\hline Освітня платформа & Он лайн курси та вебінари \\
\hline $\begin{array}{l}\text { https://www.ed- } \\
\text { era.com/courses/ }\end{array}$ & $\begin{array}{l}\text { Он лайн курси: «Робота вчителів початкових класів з } \\
\text { дітьми із особливими освітніми потребами», } \\
\text { «Недискримінаційний підхід у навчанні», «Участь } \\
\text { батьків у організації інклюзивного навчання», } \\
\text { «Колошкільне дитинознавство», «Он лайн курс для } \\
\text { вчителів початкової школи». }\end{array}$ \\
\hline $\begin{array}{l}\text { https://vseosvita.ua/w } \\
\text { ebinar }\end{array}$ & $\begin{array}{l}\text { Вебінари: «Арт-терапія в педагогічній практиці. } \\
\text { Діагностичні техніки», «Ефективність методу } \\
\text { асоціативних символів на початковому етапі } \\
\text { вивчення англійської мови», «Особливості вивчення } \\
\text { англійської мови у } 1 \text { класі за методом асоціативних }\end{array}$ \\
\hline
\end{tabular}




\begin{tabular}{|c|c|}
\hline & $\begin{array}{l}\text { символів», «Хто вони: діти з особливими освітніми } \\
\text { потребами?», «Неуспішність учнів. Чому їм важко } \\
\text { вчитися?», «Змішане навчання - ключ до змін», «Як } \\
\text { впливають очікування вчителя на успішність учнів», } \\
\text { «Соціальна інклюзія в Новій українській школі» тощо. }\end{array}$ \\
\hline $\begin{array}{l}\text { https://elt.oup.com/cat } \\
\text { alogue/items/global/te } \\
\text { acher_development/o } \\
\text { xford_teachers_acad } \\
\text { emy_online/ }\end{array}$ & $\begin{array}{l}\text { Он лайн курси: «Teaching learners with dyslexia», } \\
\text { «Teaching learners with SEN». }\end{array}$ \\
\hline $\begin{array}{l}\text { https://www.futurelear } \\
\text { n.com/courses/catego } \\
\text { ries/teaching-courses }\end{array}$ & $\begin{array}{l}\text { Он лайн курси: «Education for All: Disability, Diversity } \\
\text { and Inclusion», «Dyslexia and Foreign Language } \\
\text { Teaching», «Understanding Autism», «Good Practice in } \\
\text { Autism Education», «Inclusive learning and teaching } \\
\text { environment», «The right to education», cepiя курсів } \\
\text { «Teaching for success», «Child protection for teachers», } \\
\text { "Understanding Diversity and Inclusion» тощо. }\end{array}$ \\
\hline $\begin{array}{l}\text { https: } \\
\text { org/le }\end{array}$ & $\begin{array}{l}\text { Он лайн курс «Managing ADHD, Autism, Learning } \\
\text { Disabilities, and Concussion in School» }\end{array}$ \\
\hline
\end{tabular}

Навчальний контент україномовних та англомовних освітніх платформ ed-era.com, vseosvita.ua, futurelearn.com, coursera.org нами було обрано та проаналізовано з позиції: 1) наявності на них курсів та вебінарів із різноманітних питань організації та впровадження концептуальних ідей та положень інклюзивного навчання в заклади загальної середньої освіти; 2) практичної спрямованості контенту для того, щоб учитель, узявши участь у курсі або прослухавши вебінар, зміг використати ті підходи, матеріали, які були в них представлені, в професійній діяльності, коли в його класі поряд із дітьми типового розвитку навчаються 2-3 дитини 3 особливими освітніми потребами; 3) зручності інтерфейсу платформи для навчання на курсі або перегляду вебінару; 4) безпосередньо змістового наповнення курсу або вебінару; 5) якості он лайн зв'язку з учасниками курсу або вебінару; 6) фінансової доступності для учасників. табл. 2.

Характеристику контенту за обраними критеріями подано в

Завдання й заходи онлайн-курсів і вебінарів покликані мотивувати вчителів і залучати їх до роботи в інклюзивному освітньому середовищі. Наприклад, у кожному тижневому блоці онлайн-курсу «Освіта для всіх: інвалідність, різноманітність і інклюзія» $є$ розділ розминки, історичні фракти та інклюзивні практики, різні типи статей з гіперпосиланнями, перегляд відео, приклади з навчальної практики, вікторини та розділи обговорення. Учителям пропонується обговорити побачене та почуте в чатах. 
Технологічна характеристика освітніх платформ, на яких розміщено онлайн курси та вебінари, що сприяють розвитку інклюзивної компетентності вчителів

\begin{tabular}{|c|c|c|c|c|c|}
\hline $\begin{array}{c}\text { Критерії } \\
\text { оцінювання }\end{array}$ & $\begin{array}{c}\text { https://w } \\
\text { ww.ed- } \\
\text { era.com/c } \\
\text { ourses/ }\end{array}$ & $\begin{array}{l}\text { https://vs } \\
\text { eosvita.u } \\
\text { a/webinar }\end{array}$ & $\begin{array}{c}\text { https://elt. } \\
\text { oup.com/ } \\
\text { catalogue } \\
\text { /items/glo } \\
\text { bal/teach } \\
\text { er_develo } \\
\text { pment/oxf } \\
\text { ord_teach } \\
\text { ers_acad } \\
\text { emy_onli } \\
\text { ne/ }\end{array}$ & $\begin{array}{c}\text { https:// } \\
\text { www.fut } \\
\text { urelearn } \\
\text {.com/co } \\
\text { urses/c } \\
\text { ategorie } \\
\text { s/teachi } \\
\text { ng- } \\
\text { courses }\end{array}$ & $\begin{array}{c}\text { https://www } \\
\text {.coursera.o } \\
\text { rg/learn/ }\end{array}$ \\
\hline $\begin{array}{l}\text { Наявність } \\
\text { курсів і } \\
\text { вебінарів із } \\
\text { різноманітних } \\
\text { питань } \\
\text { організації та } \\
\text { впровадження } \\
\text { концептуаль- } \\
\text { них ідей та } \\
\text { положень } \\
\text { інклюзивного } \\
\text { навчання в } \\
\text { ЗзсО }\end{array}$ & $\begin{array}{l}\text { Обмеже- } \\
\text { на } \\
\text { кількість } \\
\text { курсів. }\end{array}$ & $\begin{array}{l}\text { Значна } \\
\text { кількість } \\
\text { вебінарів } \\
\text {. }\end{array}$ & $\begin{array}{l}\text { Обмеже- } \\
\text { на } \\
\text { кількість } \\
\text { курсів. }\end{array}$ & $\begin{array}{l}\text { Значна } \\
\text { кіль- } \\
\text { кість } \\
\text { курсів. }\end{array}$ & $\begin{array}{l}\text { Обмежена } \\
\text { кількість } \\
\text { курсів. }\end{array}$ \\
\hline $\begin{array}{l}\text { Практична } \\
\text { спрямованість } \\
\text { контенту }\end{array}$ & Так. & Так. & Так. & Так. & $\begin{array}{l}\text { Контент } \\
\text { практично } \\
\text { спрямова- } \\
\text { ний, проте } \\
\text { містить } \\
\text { багато } \\
\text { теорії, хоча } \\
\text { цікавої та } \\
\text { важливої. }\end{array}$ \\
\hline $\begin{array}{l}\text { Зручність } \\
\text { інтерфейсу }\end{array}$ & $\begin{array}{l}\text { Інтер- } \\
\text { фейс } \\
\text { зручний. }\end{array}$ & $\begin{array}{l}\text { Інтер- } \\
\text { фейс } \\
\text { зручний. }\end{array}$ & $\begin{array}{l}\text { Інтер- } \\
\text { фейс } \\
\text { зручний. }\end{array}$ & $\begin{array}{l}\text { Інтер- } \\
\text { фейс } \\
\text { зручний }\end{array}$ & $\begin{array}{l}\text { Інтерфейс } \\
\text { не дуже } \\
\text { зручний. }\end{array}$ \\
\hline $\begin{array}{l}\text { Змістове } \\
\text { наповнення }\end{array}$ & $\begin{array}{l}\text { На } \\
\text { високому } \\
\text { рівні. }\end{array}$ & $\begin{array}{l}\text { На } \\
\text { високому } \\
\text { рівні. }\end{array}$ & $\begin{array}{l}\text { На } \\
\text { високому } \\
\text { рівні. } \\
\end{array}$ & $\begin{array}{l}\text { На } \\
\text { високо- } \\
\text { му рівні }\end{array}$ & $\begin{array}{l}\text { На } \\
\text { високому } \\
\text { рівні. }\end{array}$ \\
\hline $\begin{array}{l}\text { Якість он лайн } \\
\text { зв'язку з } \\
\text { учасником }\end{array}$ & $\begin{array}{l}\text { Зв'язок } \\
\text { передба- } \\
\text { чено; має } \\
\text { місце }\end{array}$ & $\begin{array}{l}\text { Зв'язок } \\
\text { передба- } \\
\text { чено }\end{array}$ & $\begin{array}{l}\text { Зв'язок } \\
\text { передба- } \\
\text { чено; } \\
\text { бракує }\end{array}$ & $\begin{array}{l}\text { Зв'язок } \\
\text { перед- } \\
\text { бачено; } \\
\text { має }\end{array}$ & $\begin{array}{l}\text { Зв'язок } \\
\text { передбаче } \\
\text { но, але } \\
\text { незрозумі- }\end{array}$ \\
\hline
\end{tabular}




\begin{tabular}{|c|c|c|c|c|c|}
\hline & $\begin{array}{l}\text { можли- } \\
\text { вість } \\
\text { відстежу- } \\
\text { вати } \\
\text { прогрес } \\
\text { учасни- } \\
\text { ком. }\end{array}$ & & $\begin{array}{l}\text { можли- } \\
\text { вості } \\
\text { відстежу- } \\
\text { вати } \\
\text { прогрес } \\
\text { учасни- } \\
\text { ком. }\end{array}$ & $\begin{array}{l}\text { місце } \\
\text { можли- } \\
\text { вість } \\
\text { відсте- } \\
\text { жувати } \\
\text { прогрес } \\
\text { учасни- } \\
\text { ком. }\end{array}$ & $\begin{array}{l}\text { ло, як ним } \\
\text { користува- } \\
\text { тися; має } \\
\text { місце } \\
\text { можливість } \\
\text { відстежува } \\
\text { ти прогрес } \\
\text { учасником. }\end{array}$ \\
\hline $\begin{array}{l}\text { Фінансова } \\
\text { доступність }\end{array}$ & $\begin{array}{l}\text { Участь та } \\
\text { серти- } \\
\text { фікат } \\
\text { безкош- } \\
\text { товні. }\end{array}$ & $\begin{array}{l}\text { Участь } \\
\text { безкош- } \\
\text { товна, } \\
\text { вартість } \\
\text { сертифі- } \\
\text { кату } \\
\text { доступна. }\end{array}$ & $\begin{array}{l}\text { Доступна } \\
\text { безкош- } \\
\text { товна } \\
\text { демовер- } \\
\text { сія курсу, } \\
\text { вартість } \\
\text { участі } \\
\text { висока. }\end{array}$ & $\begin{array}{l}\text { Участь } \\
\text { безкош } \\
\text { товна, } \\
\text { вар- } \\
\text { тість } \\
\text { сертифі } \\
\text { кату } \\
\text { висока. }\end{array}$ & $\begin{array}{l}\text { Участь } \\
\text { безкоштов- } \\
\text { на, } \\
\text { сертифікат } \\
\text { не } \\
\text { передбаче } \\
\text { но. }\end{array}$ \\
\hline
\end{tabular}

Таким чином, удосконалена організація навчання вчителів у системі післядипломної освіти має містити: 1) діагностування рівня наявної інклюзивної компетентності (контрольну роботу) перед початком занять; 2) теоретичну частину - лекційні заняття, на яких слухачів, крім стандартних лекцій та ознайомлення 3 переліком літератури, мають ознайомити з інформацією про освітні платформи з онлайн курсами та вебінарами для вчителів в Інтернеті. Учителі самостійно можуть обрати онлайн курси та вебінари для участі; 3) педагогічну практику (спостереження в інклюзивних класах) з подальшим аналізом побачених уроків; 4) семінарські заняття, до яких слухачі, використовуючи літературні першоджерела, інформацію, отримані під час педагогічної практики, а також знання, отримані на онлайн-курсах і вебінарах, готують повідомлення на запропоновані їм теми; 5) діагностування рівня наявної інклюзивної компетентності (контрольну роботу) після закінчення занять.

Висновки і перспективи подальших досліджень. У сучасних умовах стрімкого розвитку інформаційно-комунікаційних технологій навчальний процес у закладах післядипломної педагогічної освіти має гнучко та своєчасно реагувати на зміни в освітньому просторі. Зокрема це зумовлено різким збільшенням у закладах загальної середньої освіти дітей з особливими освітніми потребами та, відповідно, необхідністю роботи вчителя 3 такими учнями, тобто розвитку їхньої інклюзивної компетентності. Це вимагає від закладів післядипломної педагогічної освіти удосконалення змісту та методики навчання на курсах підвищення кваліфікації, зокрема шляхом модернізації та поліпшення змісту теми «Технології інклюзивного навчання» діючих програм післядипломної підготовки.

У зв'язку з міжнародною актуальністю онлайн-навчання наше дослідження дає можливість трансформувати систему післядипломної 
педагогічної освіти на систему, здатну швидко реагувати на потреби вчителів у розширенні їх професійних можливостей щодо використання IКТ-ресурсів не тільки під час очного і дистанційного навчання, а також у неформальній та інформальній освіті. Педагоги та розробники курсів у сфері інклюзивної освіти, у сфері післядипломної освіти як в Україні, так і за кордоном, також можуть використовувати результати даного дослідження.

Перспективи подальших досліджень у цій області ми бачимо в розробці рекомендацій для різних категорій учителів щодо використання ІКТ для розвитку власної інклюзивної компетентності як невід'ємної складової їхньої професійної компетентності з урахуванням специфіки предметів шкільного циклу.

\section{Список використаних джерел}

Альохіна, С. \& Антонюк, Л. (2010). Формування готовності педагогічних кадрів до роботи з дітьми з особливими освітніми потребами. Нова педагогічна думка, 1, 121-123.

Бовкуш, К.П. (2014). Основні засади формування інклюзивної компетентності педагога. Молодий вчений, 7(10), 158-160.

Бойчук, Ю. Д., Бородіна, О. С. \& Микитюк, О. М. (2015). І Інклюзивна компетентність майбутнього вчителя основ здоров'я: монографія. Харків: ХНПУ імені Г.С.Сковороди.

Гета, А. В., Заіка, В. М. \& Коваленко, В. В. (2018). Сучасні засоби IКT підтримки інклюзивного навчання: навч. посібник. Полтава: ПУЕТ.

Голодюк, Л. (2009). Основні засади фрормування ІКТ-компетентності вчителя-предметника. Постметодика, 4, 41-45.

Казачінер, О. С. (2017). Післядипломна освіта як важливий чинник розвитку інклюзивної компетентності сучасного вчителя фрілологічних дисциплін. Вісник Черкас. нац. ун-ту. Сер.: Педагогічні науки, 9, 87-91.

Карташова, Л. А., Пліш, І. В. \& Бахмат, Н. В. (2018). Розвиток цифрової компетентності педагога в інформаційно-освітньому середовищі закладу загальної середньої освіти. Інформаційні технології $i$ засоби навчання, 6 (68), 193-205.

Носенко, Ю. Г. (2016). Актуальність дослідження проблеми впровадження комп'ютерно орієнтованої підтримки інклюзивного навчання учнів 3Н3. Педагогіка здоров'я: зб. наук. праць VI Всеукраїнської науково-практичної конференції ХНПУ ім. Г.С. Сковороди, 679681.

Овчарук, О. В., Гриценчук, О. О., Іванюк, І. В., Кравчина, О. Є., Малицька, І.Д. \& Сороко, Н.В.(2018). Європейський досвід розвитку цифрової компетентності вчителя в контексті сучасних освітніх реформ. Інформаційні технології $і$ засоби навчання, 
3 (65), 317-336.

Хафризуллина, И.Н. (2007). Формирование профессиональной компетентности педагога общеобразовательной школы в работе с детьми с особыми образовательными потребностями. Вестник Костромского государственного университета им. Н.А. Некрасова. Серия: Педагогика. Психология. Социальная работа. Ювенология. Социокинетика, 13 (1), 83-88.

Хитрюк, В.В. (2014). Концепция формирования инклюзивной готовности педагогов. Вестник ЧГПУ им. И.Я. Яковлева. Педагогические науки, 1 (81), 163-169.

Чайковський, М. (2012). Інклюзивна компетентність як складова професійної компетентності суб'єктів освітнього процесу. Педагогіка і психологія проф. освіти, 2, 15-21.

\section{References (translated and transliterated)}

Al'okhina, S. \& Antonyuk, L. (2010). Formuvannya hotovnosti pedahohichnykh kadriv do roboty z dit'my z osoblyvymy osvitnimy potrebamy [Formation of pedagogical staff's readiness to work with children with special educational needs]. Nova pedahohichna dumka, 1, 121-123 [in Ukrainian].

Bovkush, K. P. (2014). Osnovni zasady formuvannya inklyuzyvnoyi kompetentnosti pedahoha [Basis of a teacher's inclusive competence formation]. Molodyy vchenyy, 7(10), 158-160 [in Ukrainian].

Boychuk, Yu. D., Borodina, O. S. \& Mykytyuk, O. M. (2015). Inklyuzyvna kompetentnist' maybutn'oho vchytelya osnov zdorov"ya [Future teacher of "Basis of health"s inclusive competence]: monohrafiya. Kharkiv: KhNPU imeni H.S.Skovorody [in Ukrainian].

Heta, A. V., Zaika, V. M. \& Kovalenko, V. V. (2018). Suchasni zasoby IKT pidtrymky inklyuzyvnoho navchannya [Modern tools of ICT-support of inclusive education]: navchal'nyy posibnyk. Poltava: PUET [in Ukrainian].

Holodyuk, L. (2009). Osnovni zasady formuvannya IKT-kompetentnosti vchytelyapredmetnyka [Basis of a certain subject teacher's inclusive competence forming]. Postmetodyka, 4, 41-45 [in Ukrainian].

Kazachiner, O. S. (2017). Pislyadyplomna osvita yak vazhlyvyy chynnyk rozvytku inklyuzyvnoyi kompetentnosti suchasnoho vchytelya filolohichnykh dystsyplin [Postgraduate education as a main factor of modern philology teacher's inclusive competence development]. Visnyk Cherkas. nats. un-tu. Ser.: Pedahohichni nauky, 9, 87-91 [in Ukrainian].

Kartashova, L. A., Plish, I. V. \& Bakhmat, N. V. (2018). Rozvytok tsyfrovoyi kompetentnosti pedahoha $v$ informatsiyno-osvitn'omu seredovyshchi zakladu zahal'noyi seredn'oyi osvity [Teacher's digital competence development in the information and educational environment of a general secondary education institution]. Informatsiyni tekhnolohiyi $i$ zasoby navchannya, 6 (68), 193-205 [in Ukrainian].

Nosenko, Yu. H. (2016). Aktual'nist' doslidzhennya problemy vprovadzhennya komp"yuterno oriyentovanoyi pidtrymky inklyuzyvnoho navchannya uchniv 
ZNZ [The relevance of the study of the problem of implementing computerbased support for students of secondary schools' inclusive education]. Pedahohika zdorov"ya: zb. nauk. prats' VI Vseukrayins'koyi naukovopraktychnoyi konferentsiyi KhNPU im. H.S. Skovorody, 679-681 [in Ukrainian].

Ovcharuk, O. V., Hrytsenchuk, O. O., Ivanyuk, I. V., Kravchyna, O. Ye., Malyts'ka, I. D. \& Soroko, N. V. (2018). Yevropeys'kyy dosvid rozvytku tsyfrovoyi kompetentnosti vchytelya $v$ konteksti suchasnykh osvitnikh reform [European experience of teacher's digital competence development in the context of modern educational reforms]. Informatsiyni tekhnolohiyi $i$ zasoby navchannya, 3 (65), 317-336 [in Ukrainian].

Hafizullina, I. N. (2007). Formirovanie professional'noj kompetentnosti pedagoga obshheobrazovatel'noj shkoly v rabote s det'mi s osobymi obrazovatel'nymi potrebnostjami [Forming a school teacher's professional competence of working with children who have special educational needs]. Vestnik Kostromskogo gosudarstvennogo universiteta im. N.A.Nekrasova. Serija: Pedagogika. Psihologija. Social'naja rabota. Juvenologija. Sociokinetika, 13 (1), 83-88 [in Russian].

Hitrjuk, V. V. (2014). Koncepcija formirovanija inkljuzivnoj gotovnosti pedagogov [Conception of teachers' inclusive readiness' forming]. Vestnik ChGPU im. I.Ja. Jakovleva. Pedagogicheskie nauki, 1 (81), 163-169 [in Russian].

Chaykovs'kyy, M. (2012). Inklyuzyvna kompetentnist' yak skladova profesiynoyi kompetentnosti sub"yektiv osvitn'oho protsesu [Inclusive competence as a part of professional competence of educational process' subjects]. Pedahohika i psykholohiya prof. osvity, 2, 15-21 [in Ukrainian].

УдК 373.2.064.1

DOI: https://doi.org/10.35387/od.2(18).2020.75-86

Квасецька Ярина Андріївна - кандидат педагогічних наук, асистент кафедри педагогіки та психології дошкільної освіти Чернівецького національного університету імені Юрія Федьковича

ORCID iD: http://orcid.org/0000-0003-4270-878X

E-mail:y.kvasetska@chnu.edu.ua

\section{ПЕДАГОГІЗАЦІЯ БАТЬКІВ В УМОВАХ ЗАКЛАДІВ ДОШКІЛЬНОЇ ОСВІТИ}

Анотація. Оәлядову статтю присвячено аналізу проблеми педагогізації батьків вихованців закладів дошкільної освіти в умовах транссрормації інфрормаційно-технологічного суспільства і зростання ролі освіти як цивілізаційного ресурсу. Здійснено огляд сучасних досліджень $i$ публікацій, ретроспективний аналіз питання взаємодії дошкільного закладу і сім'ї на різних етапах суспільного розвитку. Розкрито й уточнено сутність поняття «педагогізація», відзначено особливості його трактування в сфрері педагогіки і психології, обгрунтовано доцільність 